\title{
ANÁLISE DA CONSTITUIÇÃO DO ESTADO NOVO BRASILEIRO A PARTIR DA IDEIA DE CONSTITUCIONALISMO ANTILIBERAL DE CARL SCHMITT
}

\author{
ANALYSIS OF BRAZILIAN ESTADO NOVO CONSTITUTION FROM \\ CARL SCHMITT'S ANTILIBERAL CONSTITUTIONALISM
}

\author{
Victor Augusto de Oliveira Meira \\ victor_meira@hotmail.com
}

Sandro Alex de Souza Simões

Doutor pela Università Del Salento/Lecce. Mestre em Direito pela Universidade Federal do Pará. Professor efetivo do Centro Universitário do Estado do Pará (CESUPA). Investigador do Centro de Investigação em Teoria e História do Direito (THD) da Faculdade de Direito da Universidade de Lisboa. sandro.simoes@prof.cesupa.br

\section{Victor Sales Pinheiro}

Doutor em Filosofia pela UERJ. Mestre em Filosofia pela PUC-RIO. Professor adjunto da Universidade Federal do Pará (UFPA) e do Centro Universitário do Pará (CESUPA). vvspinheiro@yahoo.com.br

RESUMO: O artigo tem como objetivo verificar semelhanças conceituais e argumentativas entre a teoria política antiliberal de Carl Schmitt e o populismo brasileiro do Estado Novo. Procurar-se-á investigar, primeiramente, os conceitos políticos e constitucionais bem como as soluções antiliberais de Schmitt para o ciclo temporal de problemas da democracia liberal. Para tal empreitada toma-se como referência duas obras de Carl Schmitt publicadas durante a República de Weimar, "O Conceito do Político" e "A Teoria da Constituição", visando definir o conceito de político, constituição, democracia substancial, sociedade de massas e o mito carismático da figura do líder que a mobiliza para construção da unidade política nacional. A partir destes conceitos, será analisado o pensamento de Francisco Campos, principal artífice da Constituição brasileira de 1937 e conhecido como o jurista do Estado Novo, na tentativa de demonstrar uma convergência de preocupações e semelhanças de ideias acerca de um estado democrático de direito. A primeira parte da pesquisa foi realizada através de método hipotético dedutivo, com levantamento de bibliografia de Schmitt, ao passo que a segunda parte consiste na identificação de conceitos trabalhados pelo jurista alemão de forma semelhante na justificativa construída por Campos, diretamente no texto da Constituição de 1937.

PALAVRAS-CHAVE: Carl Schmitt; Constitucionalismo Antiliberal; Teoria da Constituição; Francisco Campos; Estado Novo.

ABSTRACT: The article aims to verify conceptual and argumentative similarities between Carl Schmitt's antiliberal political theory and the Brazilian populism of the Estado Novo. We will try to investigate, first, the political 
Análise da Constituição do Estado Novo brasileiro a partir da ideia de constitucionalismo antiliberal...

and constitutional concepts as well as Schmitt's anti-liberal solutions to the temporal cycle of problems of liberal democracy. For this endeavor, two works by Carl Schmitt published during the Weimar Republic are taken as reference, "The Concept of the Politician" and "The Theory of the Constitution", which defines the concept of politician, constitution, substantial democracy, mass society and the concept of political charismatic myth of the figure of the leader who mobilizes it to build national political unity. Based on these concepts, the thinking of Francisco Campos, the main author of the Brazilian Constitution of 1937 and known as the jurist of the Estado Novo, will be analyzed, in an attempt to demonstrate a convergence of concerns and similarities of ideas about a democratic state of law. The first part of the research was carried out using the hypothetical deductive method, with a survey of Schmitt's bibliography, while the second part consists of the identification of concepts worked by the German jurist in a similar way in the justification constructed by Campos, directly in the text of the Constitution of 1937.

KEYWORDS: Carl Schmitt; Antiliberal Constitutionalism; Constitutional Theory; Francisco Campos; Estado Novo.

\section{INTRODUÇÃO}

Na presente pesquisa investigaremos as ideias do jurista alemão Carl Schmitt (18881985), particularmente de seu conceito de político e democracia substancial em sua teoria política antiliberal, que estariam diretamente relacionados com o desenvolvimento do populismo brasileiro durante o Estado Novo (1937-1945).

Schmitt é notório por sua participação na estruturação teórica do NSDAP (Nationalsozialistische Deutsche Arbeiterpartei, o partido Nazista) no início dos anos 30 do século XX, bem como pela defesa intelectual dos ideais nazistas, em seu período inicial. A ascensão do populismo europeu coincide com aquela que ocorreu no Brasil, pelo que buscaremos observar eventuais elementos de influência teórica, particularmente no período de 1937 a 1945, através da obra de Francisco Campos, autor intelectual da Constituição de 1937.

Tal recorte temporal foi realizado, em específico, por ser esse período da história constitucional brasileira marcado por institutos jurídicos e políticos que tem clara semelhança com as propostas de democracia substancial e sociedade de massas na obra de Schmitt, sendo marcado pela continuidade de um projeto de Estado Nacional nos moldes do desenvolvimentismo e do populismo.

Escolheu-se como campo de análise o direito constitucional, por ser nesta área do direito que se encontram as justificativas jurídicas e políticas do regime. Compreender o que Campos, principal jurista deste período, pensa acerca de conceitos como "Constituição", "Democracia" "Povo" e a identificação que o mesmo tem com as ideias de sociedade de massas movidas por mitos irracionais (SANTOS, 2007, p. 285), permite identificar a importância das teorias de Schmitt e sua colaboração com a formação de regimes políticos tidos como autoritários.

Cabem algumas considerações prévias sobre a organização e metodologia do presente trabalho. No primeiro tópico, considerando a extensa obra teórica de Carl Schmitt, optou-se por focar em duas de suas obras mais importantes, onde há uma introdução a conceitos fundamentais utilizados por Campos na elaboração da Constituição de 1937 e na construção de sua justificativa. 
Análise da Constituição do Estado Novo brasileiro a partir da ideia de constitucionalismo antiliberal...

Tais ideias demonstram ampla convergência conceitual àquelas contidas em obras publicadas por Schmitt ainda durante a vigência da República de Weimar, "O Conceito do Político" (Der Begriff des Politischen) publicada em 1932 e "Teoria da Constituição" (Verfassungslehre), publicada em 1928.

Este foi o critério utilizado para a seleção dos tópicos deste capítulo. Na primeira parte, será feita uma abordagem descritiva do pensamento jurídico, filosófico e político de Schmitt, procurando-se, na medida das limitações do autor do texto e das traduções utilizadas, manter o sentido original das ideias do pensador alemão.

Serão abordados primeiramente os conceitos chaves acerca do entendimento que Schmitt tem do que seria "político" a partir da distinção amigo-inimigo, a ideia de independência que o político tem do jurídico e da moral, precedendo o próprio conceito de Estado, com o fito de compreender posteriormente a teorização sistemática sobre o constitucionalismo antiliberal fundado na ideia de democracia substancial. Este argumento se tornou o paradigma jurídicoconstitucional das ditaduras ocidentais do século XX, incluindo as que vigeram no Brasil, bem como tiveram forte influência na construção do imaginário político mítico que revolve a nação brasileira, sempre seduzida pelo imaginário do líder carismático.

Tal análise possibilitará compreender, no segundo capítulo, a relação destas ideias de Schmitt com a estruturação criada por Francisco Campos na Constituição de 1937, mesmo que não tenha ocorrido um diálogo direto entre os autores e estas tenham sido adaptadas pelo jurista brasileiro.

Tomando como premissas as ideias expostas nos textos de Bueno (2016) e Santos (2007), tentar-se-á verificar uma possível influência da obra política de Schmitt nos conceitos, propostas, soluções antiliberais e instrumentos jurídicos formulados por Campos, verificando-se a relação entre a justificação jurídico-constitucional do Estado Novo e a transferência do Poder Legislativo para a administração pública, com o fortalecimento de medidas como os plebiscitos e a declaração constitucional de estado de emergência, sendo estas características de um modelo de Estado pós Weimar presentes na Constituição de 1937.

Procurar-se-á expor a sutil relação de ideias entre os autores, bem como a inspiração autoritária da obra de Campos, observando-se a notável centralização do poder ao privilegiar o Poder Executivo em detrimento do Parlamento, promovendo-se o voluntarismo conservador característico do período do Estado Novo. A ideia de uma tecnocracia comandada por burocratas "capazes" (elite política) de tomar as decisões de forma objetiva, em detrimento de uma participação equânime das camadas populares no Poder e uma inépcia nos diálogos parlamentares liberais é presente na crítica de Schmitt e Campos à organização das democracias ocidentais (BUENO, 2016).

Em diversas ocasiões, Francisco Campos é descrito como fascista ou, no mínimo, é apontado como um reacionário fortemente influenciado pelas ideias nacionalistas conservadoras de Alberto Torres e Oliveira Vianna (BUENO, 2016, p. 83). Entende Santos (2007, p. 282), contudo, que o percurso político e intelectual de Campos é muito mais complexo do que tal 
Análise da Constituição do Estado Novo brasileiro a partir da ideia de constitucionalismo antiliberal...

descrição, revelando uma capacidade de adaptação a mudanças no quadro político e social, sendo problemática sua simples classificação como autoritário.

A realidade é que Campos foi um dos políticos mais ativos na configuração do Estado brasileiro durante o século XX, sendo o responsável direto pela reorganização dos sistemas educacional, legal e constitucional durante a Revolução de 1930 e no Estado Novo. Em 1937, quando elaborou o Projeto da Constituição outorgada, Campos já era o jurista mais influente na política nacional, tendo articulado o apoio a Vargas, participando diretamente do regime como ministro da Justiça e Negócios Interiores. O seu livro mais influente foi publicado neste período: "O Estado Nacional: Sua Estructura, seu Conteúdo Ideológico" (1940), no qual, além da conferência “A Política e o Nosso Tempo", estão agrupados inúmeros artigos, entrevistas e discursos oficiais (SANTOS, 2007, p. 319-320).

Pode-se afirmar que foi através do trabalho deste eminente jurista mineiro que se deu início ao processo de centralização político-constitucional no Brasil por certa interpretação do federalismo de 1891, amarrando a ideia de autoridade à tradição e à centralização da ordem imperial, observando o país já dividido pelas oligarquias regionais da república do café com leite (SANTOS, 2007, p. 281).

As raízes da influência do pensamento antiliberal de Campos podem ser encontradas mesmo antes de Schmitt, através dos conceitos que culminaram no Castilhismo (Julio Prates de Castilho) e na ideia do Estado corporativo de Oliveira Vianna, tendo também grande influência no Constitucionalismo da Era Vargas. A Corrente política liderada por Júlio Prates de Castilhos (1860-1903), com fundamento no positivismo de Augusto Comte, tinha o objetivo de realizar a ordenação social do Estado de forma ditatorial. Há um forte autoritarismo moral e foco na organização hierárquica e burocrática do Estado. O Castilhismo pode ser considerado o berço político de Getúlio Vargas, estadista gaúcho, para a futura configuração do Estado Novo, chancelando o projeto jurídico de Campos (SANTOS, 2007, 284).

No que tange ao trabalho de Oliveira Vianna, o foco foi o trabalhismo e a representação classista, que seria mais legítima do que a representação parlamentar de cunho liberal. Foi com base nessas ideias corporativistas que o governo Vargas ditou os rumos do programa de controle político das massas trabalhadoras, tendo dado início a um aumento da importância dos conselhos profissionais e a consolidação da Justiça do Trabalho. Percebe-se que o modelo varguista de poder é uma ordem voltada para os problemas característicos de uma sociedade em processo de industrialização e ainda agitada pelas movimentações operárias, tardiamente organizadas no Brasil (SANTOS, 2007, p. 284).

Esta concepção e influência prévia do diálogo de Campos com castilhismo varguista e o corporativismo de O. Vianna distinguem-se, segundo Santos (2007, p. 285), do autoritarismo nacionalista ditatorial dos integralistas como Alberto Torres, Plínio Salgado e Alceu Amoroso Lima. A distinção é que, para estes, a finalidade de um regime político seria a simples concentração da autoridade e a realização da ordem, enquanto Campos tinha uma real preocupação com a legitimação e estruturação jurídica do Estado que, em sua visão, deveria ser democrática e antiliberal, ou seja, plebiscitária e corporativa (SANTOS, 2007, p. 284). 
Análise da Constituição do Estado Novo brasileiro a partir da ideia de constitucionalismo antiliberal...

Para melhor compreensão desta visão antiliberal, faz-se necessário observar a apreciação sociológica que Campos faz, com indícios claros de influência do pensamento de Schmitt, da sociedade de massas, cujas decisões políticas somente serão possíveis através da mobilização emocional a partir de um mito. O instrumento técnico-jurídico serão as práticas plebiscitárias, previstas na Constituição de 1937 como forma de materialização da legitimação do Estado Novo, através da escolha popular direta (SANTOS, 2007, p. 285).

Campos efetivamente instituiu as bases de um sistema jurídico fundado nos poderes de uma Constituição orientada pelo estado de emergência (exceção) e ruptura institucional legítima, conceito amplamente explorado por Schmitt em sua definição do "político". Ademais, a sua legitimação plebiscitária e a estabilização posterior do regime são dependentes da autonomia e preponderância do Poder Executivo na produção legislativa chancelada pelo suporte popular à figura pessoal de Getúlio Vargas, tal como Schmitt preconizava, um líder mítico que representaria diretamente a vontade do povo.

Destarte, estes instrumentos técnicos serão mais bem analisados no segundo capítulo, onde o texto da Constituição de 1937 e sua justificativa serão perscrutados e em suas instituições jurídicas, representantes das aspirações políticas de Vargas, serão observadas as influências antiliberais de Schmitt.

O trabalho defende que este modelo definirá as técnicas jurídico-constitucionais implicadas na construção de um Executivo forte e absorvente e, apesar das consequências e falhas do projeto de governo, este tinha o objetivo de construir um novo modelo de Estado para a modernização do país, observando a realidade política antiliberal que se construía na Europa.

É necessário observar, entretanto, que se ocorreram êxitos nos apontamentos das falhas das democracias parlamentares, por outro lado o autoritarismo e o voluntarismo oriundos centralização de poder não podem ser reconhecidos como resposta a tais falhas, residindo aí a semelhança na proposta de Schmitt e Campos: ambos souberam criticar e apontar as dificuldades do regime parlamentarista sem apresentar resposta verdadeiramente democrática aos problemas que a ausência do diálogo formal entre poderes gera.

\section{PONTOS FULCRAIS DA TEORIA POLÍTICAANTILIBERAL DE CARL SCHMITT: O CONCEITO DO POLÍTICO E A DEMOCRACIA SUBSTANTIVA}

Conforme exposto em caráter introdutório, o jurista alemão Carl Schmitt (1888-1985) é hodiernamente conhecido como o autor da teorização sistemática sobre o constitucionalismo antiliberal e a democracia substancial que lhe dá conteúdo e legitimação, sendo este o paradigma jurídico-constitucional dos regimes autoritários que prevaleceram no ocidente, na $1^{\mathrm{a}}$ metade do século XX.

Isto se dá pelo fato de boa parte da historiografia e produção acadêmica especializada ser fundamentada em conceito liberal de Estado, havendo uma constante imprecisão na conceituação, sendo o termo incapaz de satisfatoriamente descrever o conteúdo de regimes como o do Estado Novo sua forma de organização política legitimada e considerada democrática. 
Análise da Constituição do Estado Novo brasileiro a partir da ideia de constitucionalismo antiliberal...

O termo mais adequado para classificar este tipo de regime político constitucional que pretende uma legitimação democrática distinta da representação parlamentar seria "antiliberal", sendo este, ao mesmo tempo:

[...] a) uma crítica ao direito, à política e às instituições liberais; b) uma aproximação constitucional vinculada à ideia de soberania como decisão personificada; c) um modelo de ordem democrática que se realiza pela mobilização irracional das massas por um César; e d) uma reorganização do Estado fundada na burocratização da legislação (SANTOS, 2007, p. 282).

Estas quatro características resumem o constitucionalismo antiliberal cuja relação entre povo e governo pode se estabelecer tanto pela existência de corporações profissionais como através do plebiscito, havendo legitimidade jurídica e constitucional que não é imposta pela força, mas pela vontade popular da maioria e estruturada por uma elite intelectual que compõe a burocracia do Poder Executivo, com a restrição das funções dos demais Poderes da República (SANTOS, 2007, p. 282).

Schmitt antevê a possibilidade da suspensão do direito autorizada pelo próprio direito (Estado de Exceção previsto e regulamentado). Esta engenharia constitucional, que opera por instrumentos de exceção, justifica-se pela necessidade dos fatos políticos da época (notadamente conflitos internos ou mesmo ameaças externas) e vale-se de um modo específico de legitimação democrática plebiscitária. É deste modo que o Poder Executivo pode exercer a sua vontade livre de restrições jurídicas e controle de outros poderes, somente com fulcro na "vontade do povo" através de um processo de aclamação (SANTOS, 2007, p. 282-283).

O conceito de democracia substancial e a necessária homogeneidade nacional para a formação do povo em uma unidade que dá substrato ao regime político será a base do trabalho constitucional de Schmitt e será tratada em subtópico específico (2.2).

Antes de adentrar na Teoria da Constituição do autor, contudo, é necessário tratar do que seria uma política antiliberal de Schmitt, fundada na diferenciação amigo-inimigo, no conceito de Estado de Exceção e de unidade política da nação, eis que tais ideias são observáveis na estruturação jurídica e constitucional do Estado Novo de Campos. É o que se propõe no próximo tópico, ao abordar-se uma de suas obras mais estudadas.

\subsection{O CONCEITO DO POLÍTICO}

Certamente dentre as obras acadêmicas mais relevantes para o estudo da teoria e filosofia política do século XX está a obra "O conceito do Político", de Carl Schmitt, publicada no ano de 1932. Neste estudo, Schmitt busca o real conceito de "político", a fim de diferenciar esta categoria da ação humana de outras como a moral, religião e o direito.

O autor afirma que há uma confusão generalizada quando se trata da definição do que é político, uma vez que o "político" seria normalmente equiparado de alguma forma ao que 
Análise da Constituição do Estado Novo brasileiro a partir da ideia de constitucionalismo antiliberal...

é estatal e este também seria definido com base no que é político, criando assim "um círculo vicioso" nada satisfatório (SCHMITT, 2008, p. 20-21).

Também irá criticar as definições do que é "político" feitas pelo Direito, uma vez que estas não teriam por objeto uma definição geral, mas sim a criação de pretextos práticos para delimitar o âmbito de incidência de algumas normas positivas do Estado, como as do direito administrativo ou do controle jurisdicional. Além disso, mesmo quando buscam uma conceituação geral, as definições jurídicas se limitam a uma remissão ao conceito de "Estado" (SCHMITT, 2008, p. 23).

Ele ainda criticará definições como a do Direito administrativo Francês, que dispunham os atos de governo como "políticos" e os atos administrativos como "apolíticos". A distinção seria descabida, primeiro porque a política não estaria restrita ao âmbito estatal, segundo porque nos estados totalitários o ente estatal passa a se imiscuir em todos os aspectos da vida humana, de forma então que tudo seria político nesta definição clássica (SCHMITT, 2008, p. 22-25).

Schmitt entende, ainda, que é um verdadeiro erro equiparar o conceito de Estado ao conceito de sociedade humana em geral (SCHMITT, 2008, p. 26). Assim, ele irá buscar um conceito de político que não faça referência ao Estado e que seja autônomo em relação à moral, à religião e ao Direito.

Os cientistas políticos da época (anos 20 e 30 do século XX) sempre abordavam o conceito do político como algo relativo ao Estado. Desta forma, o pensador alemão percorre um caminho diferente na tentativa de criar um conceito autônomo para a ação política, uma espécie de busca por sua essência, através da diferenciação com outras formas de agir humano. Segundo Schmitt (2008, p. 27), a moral consiste em uma diferenciação entre o bom e o mau, o estético entre o belo e o feio, o econômico entre o útil e o prejudicial, enquanto o político residiria na diferenciação entre "amigo" e "inimigo". Esta diferenciação poderia ser entendida como:

O propósito de caracterizar o extremo grau de intensidade de uma união ou separação, de uma associação ou dessassociação, podendo existir na teoria e na prática, sem que, simultaneamente, tenham que ser empregadas todas aquelas diferenciações morais, estéticas, econômicas ou outras (SCHMITT, 2008, p. 28).

Repudiando qualquer suavização de sua definição, Schmitt deixa expresso que o inimigo não é o "inimigo pessoal", mas sim o "inimigo público", aquele a quem uma coletividade se opõe. E se opor seria entender a quem o conjunto de pessoas estaria disposto a combater, mesmo que eventualmente (SCHMITT, 2008, p. 27).

A ideia de combate não seria metafórica ou simbólica. O combate só poderia adquirir seu sentido real caso se referisse à efetiva e concreta "possibilidade de morte física" (SCHMITT, 2008, p. 25).

A diferenciação seria autônoma porque o inimigo político não precisa ser moralmente mau, feio ou um concorrente econômico (SCHMITT, 2008, p. 26). O próprio uso do termo "político" provaria isso, uma vez que, segundo o autor, se costuma utilizar o termo "político" de forma pejorativa, a fim de diferenciá-lo do que é técnico, do que é "apolítico" (SCHMITT, 2008, p. 33). 
Análise da Constituição do Estado Novo brasileiro a partir da ideia de constitucionalismo antiliberal...

A confusão entre o que é político e o que é moral, religioso, entre outros, ocorreria pelo fato de que normalmente são estas contraposições (da moral e da religião, por exemplo) que normalmente desencadeiam o fato decisivo para o agrupamento social e, consequentemente, para o combate (SCHMITT, 2008, p. 38).

Apesar de dizer que sua definição não implica que os povos vivam necessariamente em guerra ou em inimizade perpétua contra um mesmo inimigo, o autor nega a ideia de neutralidade, afirmando que esta representaria na verdade o fim da vida política (SCHMITT, 2008, p. 37).

Schmitt (2008, p. 38-39) afirmará que até mesmo a "paz", a "neutralidade", a "humanidade" e o "apolítico" podem ser usados como justificativas para combates e guerras, justamente porque serão utilizadas para eleger os inimigos que seriam opositores da paz, inimigos da neutralidade, desumanos ou políticos, identificando critérios de subjetividade na escolha.

Destarte, todas as contraposições, sejam elas morais, religiosas, científicas, étnicas ou de outras categorias, somente se caracterizam como políticas na medida em que possuem força para agrupar os humanos em amigos e inimigos. Toda dicotomia seria tão mais política quanto mais ela aproxime os homens do ponto extremo do combate, desta divisão conceitual pública entre amigos e inimigos (SCHMITT, 2008, p. 31-39).

Retomando o debate sobre o Estado, percebe-se de imediato a impactante frase inicial de seu livro: "O conceito de Estado pressupõe o conceito do político" (SCHMITT, 2008, p. 19). A conclusão do autor é, portanto, que o conceito de político precede o conceito de Estado, sendo distinto deste.

Nesse diapasão, Schmitt (2008, p. 41) entenderá que o político pode exercer sua força nos mais diversos âmbitos da vida humana e não está restrito a um domínio próprio. Assim, se as forças antagônicas, econômicas, culturais ou religiosas forem fortes o suficiente para definirem, por si só, a decisão fundamental sobre quem é o inimigo, elas terão se convertido na nova substância da unidade política no lugar do Estado.

Demais disso, o autor alemão irá utilizar como exemplo o fato de que mesmo o império de Bismarck, tido como absolutamente soberano e onipotente à época, não teve forças para vencer o que ele chama de "luta cultural" contra a "Igreja de Roma" (Igreja Católica), havendo a prevalência política da última (SCHMITT, 2008, p. 45).

Também irá afirmar, como exemplo hipotético, que, em sua época, as igrejas dificilmente conseguiriam convencer seus frequentadores a abandonar seus sindicatos e os próprios dificilmente convenceriam seus membros a abandonar a Igreja, de forma que ambas as instituições não detêm grande poder para definir quem são os inimigos, denotando a ausência de unidade política em torno dessas organizações sociais (SCHMITT, 2008, p. 44).

Para o autor, a unidade política de uma nação seria em essência a unidade normativa de afirmação do inimigo, sendo irrelevante em quais forças (igreja, economia, partidos políticos, universidades, Estado etc.) repousariam os últimos motivos psíquicos. A unidade iria pressupor a possibilidade real de existência de um inimigo e, com ela, a de outra unidade política oposta.

O papel do Estado seria o de definir o inimigo externo, uma vez que o chamado "Estado normal" ofertaria aos seus cidadãos uma pacificação, tranquilidade e ordem internas. Seria 
Análise da Constituição do Estado Novo brasileiro a partir da ideia de constitucionalismo antiliberal...

inclusive essa situação "normal” que possibilitaria que as normas jurídicas possam ter eficácia (SCHMITT, 2008, p. 49).

Esta busca de pacificação interna levaria o Estado a afirmar sua unidade política determinando por si mesmo "inimigos internos". Estes inimigos internos estariam presentes de modo geral no Direito Público dos diversos Estados, como, por exemplo, na figura dos polemios nas repúblicas gregas, dos hostis do Direito Romano, dos inimigos da democracia de Atenas, dos proscritos, dos banidos, exilados, os heterodoxos, os hereges etc. (SCHMITT, 2008, p. 49).

Mesmo em Estados tidos como pacíficos, o Estado elegeria e exerceria força contra aqueles que tem como inimigos, ainda que, às vezes, de forma mais moderada. Seriam os casos das leis de confiscos, expatriações, proibições de determinados tipos de organização ou reuniões de determinados grupos sociais. A sociedade econômica também possuiria meios suficientes para expulsar e remover de circulação os "vencidos e fracassados" por meio da concorrência e até mesmo alguém tido como perturbador da ordem pública (ex.: protestantes), exercendo a decisão política de modo não violento e alegadamente "pacífico" (SCHMITT, 2008, p. 52).

$\mathrm{O}$ autor ainda afirmará que qualquer povo só terá existência política, na medida em que pode decidir por si próprio a distinção entre amigos e inimigos. Quando o povo perde essa capacidade, ele perde sua existência política e passa a ser submisso a opção política de outrem. Isto ocorreria, por exemplo, ao ceder o poder de decisão política a organismos internacionais como “A Liga das Nações”, observando o exemplo alemão, contexto da vida do autor (SCHMITT, 2008, p. 53-55).

Para Schmitt (2008, p. 62), estes organismos internacionais unicamente introduziriam novas formas e possibilidades de conflitos, permitindo guerras e até fomentando guerras contra os inimigos. A ideia de um Estado mundial (internacional) seria uma contradição em termos, posto que seria impossível um Estado que não exercesse a decisão política fundamental de eleger inimigos.

Optou-se por iniciar a exposição sobre Schmitt com a sua distinção entre amigo-inimigo e sua concepção do político em razão da própria organização de seu pensamento filosófico. O texto discutido é precedido por uma famosa teoria constitucional deste mesmo autor, a qual estabelece conceitos fundamentais como democracia substancial.

\subsection{TEORIA DA CONSTITUIÇÃO: A DEMOCRACIA SUBSTANCIAL}

Carl Schmitt se tornou um constitucionalista relevante durante a República de Weimar, sendo respeitado internacionalmente por suas contribuições na conceituação da lei fundamental do estado moderno burguês. Dentre sua vasta obra, destaca-se o livro "Teoria Constitucional", publicado pela primeira vez em 1928, o qual servirá de base analítica para este trabalho.

Aqui, pretende-se expor conceitos fundamentais para Schmitt, como Constituição, Igualdade e Democracia, eis que basilares em sua concepção do que é uma realidade política, bem como sua crítica ao Estado Liberal Burguês que, em sua visão, ao se fundamentar na ideia 
Análise da Constituição do Estado Novo brasileiro a partir da ideia de constitucionalismo antiliberal...

de pluralismo, acaba por gerar um distanciamento entre povo e governo, afastando-se de um poder político realmente válido.

É necessário ressaltar que o contexto histórico e político em que o autor estava inserido (República de Weimar, pós $1^{\text {a }}$ Guerra Mundial) levou-o, naturalmente, a criticar o que naquele momento não apresentava nenhuma eficácia no campo político e econômico na Alemanha.

Schmitt foca, portanto, em desenvolver uma doutrina cujo alvo foi a fraqueza constitucional deste Estado democrático-liberal alemão. Em sua obra Verfassungslehre (Teoria da Constituição) (1982 [1928]), o jurista realiza uma análise pormenorizada de cada tipo de constituição e instituição política liberal, vista como fraca, apresentando seu modelo constitucional como a saída para a crise da democracia em contrapartida ao crescimento da influência comunista da URSS.

Ele preconizava a representação como relação de identidade entre um determinado povo e seu líder, independentemente de intermediação institucional. O processo de governo pela opinião pública, a democracia substancial, uma espécie de unidade entre governantes e povo, "dominantes" e "dominados".

O jurista também teceu fortes críticas ao modelo de democracia representativa, por julgar que as instâncias burocráticas promoviam o afastamento do povo de seus líderes e, consequentemente, maculavam a real decisão política que conferia legitimidade ao ordenamento jurídico. Esta falta de homogeneidade e aclamação dos líderes pelo povo era crucial para o fracasso do modelo liberal segundo o jurista alemão, que defendeu o modelo que chamou de democracia substancial, vista como a materialização do poder de governo do Estado (SANTOS, 2007, p. 283).

Para operacionalizar seu ideal de democracia e poder político, Schmitt buscou criar um sistema constitucional que representasse essa unidade. Sua Teoria da Constituição tem como base uma crítica ao Estado burguês de Direito, tal como se depreende diretamente do prólogo da supracitada obra (SCHMITT, 1982, p. 22-23).

O autor inicia pela exposição de modelos de Constituição de tradições passadas (absoluto, relativo, positivo), fazendo uma comparação entre estes, para chegar no que considera o modelo ideal: a constituição positiva (SCHMITT, 1982, p. 29-44). Veja-se a definição clássica do autor, acerca da Constituição em sentido positivo, diferenciando-a do conceito absoluto:

\footnotetext{
La Constitución no es, pues, cosa absoluta, por cuanto que no surge de sí misma. Tampoco vale por virtud de su justicia normativa o por virtud de su cerrada sistemática. No se da a sí misma, sino que es dada por una unidad política concreta. Al hablar, es tal vez posible decir que una Constitución se establece por sí misma sin que la rareza de esta expresión choque en seguida. Pero que una Constitución se dé a sí misma es un absurdo manifiesto. La Constitución vale por virtud de la voluntad política existencial de aquel que la da. Toda especie de normación jurídica, y también la normación constitucional, presupone una tal voluntad como existente (SCHMITT, 1982, p. 46).
}

Para Schmitt (1982, p. 46), a Constituição é dada pela unidade política concreta, já existente e é fixada por meio de ato decisional do titular do poder constituinte. Ou seja, não é absoluta, 
Análise da Constituição do Estado Novo brasileiro a partir da ideia de constitucionalismo antiliberal...

pois não surge de forma espontânea, fundamentada em si mesma, mas extrai sua validade de uma vontade política existente. A Constituição seria a decisão política do titular do poder constituinte, que confere validade às normas do ordenamento jurídico. Explica Schmitt (1982, p. 46):

Las leyes constitucionales valen, por el contrario, a base de la Constitución y presuponen una Constitución. Toda ley, como regulación normativa, y también la ley constitucional, necesita para su validez en último término una decisión política previa, adoptada por un poder o autoridad políticamente existente. [...] La distinción entre Constitución y ley constitucional es sólo posible, sin embargo, porque la esencia de la Constitución no está contenida en una ley o en una norma. En el fondo de toda normación reside una decisión política del titular del poder constituyente, es decir, del Pueblo en la Democracia y del Monarca en la Monarquía auténtica.

Diferenciando conceitualmente Constituição de leis constitucionais, o autor afirmará que a primeira é apenas decisão política fundamental de uma unidade política, manifestada através do titular do Poder Constituinte. Esta decisão refere-se à concreta forma de organização e manifestação política da unidade que a proferiu. Assim, só serão "Norma Fundamental" as disposições que parecem de singular importância política às pessoas e grupos politicamente influentes em um dado momento. Como exemplo, ele dirá que a Constituição francesa de 1791 é a decisão política do povo francês a favor da Monarquia Constitucional, havendo uma unidade política deste povo em torno desta decisão (SCHMITT, 1982, p. 47).

Em visão consideravelmente distinta da predominante no Constitucionalismo moderno, Schmitt (1982, p. 48) dirá que determinações constitucionais contidas no preâmbulo e frases como "o poder do Estado emana do povo", não são leis, nem mesmo leis constitucionais, posto que estão em categoria superior à das leis e das demais normas constitucionais. Estas frases seriam expressão da decisão política fundamental, que apresentam a forma política de ser do povo alemão e constituem o pressuposto básico para todas as normas posteriores, inclusive das normas constitucionais.

Até mesmo a supressão revolucionária de uma Constituição pode significar meramente uma "reforma constitucional", caso a nova Carta Magna mantenha a Decisão Política Fundamental do povo. Nesse sentido, a Constituição de Weimar, surgida mediante revolução, poderia ser encarada como mera reforma constitucional do Reich alemão (SCHMITT, 1982, p. 109).

O Estado de Exceção previsto expressamente em constituições seria um exemplo disso na medida em que permite a supressão de direitos e garantias previstos no texto constitucional, mas lhe é vedado alterar ou atentar contra a decisão política fundamental, a substância própria da Constituição não pode ser atingida. Diz o autor:

La Constitución es intangible, mientras que las leyes constitucionales pueden ser suspendidas durante el estado de excepción, y violadas por las medidas del estado de excepción[...] Todo esto no atenta a la decisión política fundamental ni a la sustancia de la Constitución, sino que precisamente se da en servicio del mantenimiento y subsistencia de la misma. Por eso sería absurdo hacer de la intangibilidad de la Constitución una intangibilidad de cada una de las leyes constitucionales y ver en 
Análise da Constituição do Estado Novo brasileiro a partir da ideia de constitucionalismo antiliberal...

cada una de las prescripciones legal-constitucionales un obstáculo insuperable para la defensa de la Constitución en su conjunto. Esto, en la práctica, no sería más que colocar la ley particular por encima del conjunto de la forma de existencia política, cambiando en su contrario el sentido y finalidad del estado de excepción (SCHMITT, 1982, p. 50).

É nesse contexto de luta ou combate político que Schmitt dirá que cada partido ou grupo só reconhecerá como legitima a Constituição que corresponda aos seus postulados políticos (SCHMITT, 1982, p. 58).

Para exemplificar melhor a ideia, Schmitt menciona que na mesma época da República de Weimar (início do século XX), havia outros tipos de Constituição (e não somente a do modelo dominante na Europa, que é a do Estado Burguês de Direito) tais como as da Rússia bolchevista e da Itália fascista. Ao descrever o conceito burguês-liberal de Constituição, Schmitt apresenta o embrião de sua teoria constitucional, eis que critica o modelo liberal justamente pela sua visão negativa do Estado diante do indivíduo (cidadão), restringindo sua atuação ao prever limitações ao seu poder.

Schmitt entende que o Estado burguês de Direito é limitado pois só pode integrar uma parte da total Constituição do Estado, enquanto que a outra parte contém a decisão positiva acerca da forma da existência política e que, em razão desta dupla estrutura da constituição liberal (proteção da liberdade individual e elemento de vontade política que define a forma de governo), todos os conceitos centrais deste modelo, como a lei, acabam sendo incertos. Segue a passagem em que o autor explicita tal entendimento:

[...] La tendencia del Estado burgués de Derecho va en el sentido de desplazar lo político, limitar en una serie de normaciones todas las manifestaciones de la vida del Estado y transformar toda la actividad del Estado en competencias, limitadas en principio, rigurosamente circunscritas. De aquí resulta ya que lo característico del Estado burgués de Derecho sólo puede integrar una parte de la total Constitución del Estado, mientras que la otra parte contiene la decisión positiva acerca de la forma de la existencia política. Las Constituciones de los actuales Estados burgueses están, pues, compuestas de dos elementos: de un lado, los principios del Estado de Derecho para la protección de la libertad burguesa frente al Estado; de otro, el elemento político del que ha de deducirse la forma de gobierno (Monarquía, Aristocracia o Democracia, o un status mixtus) propiamente dicha. En la reunión de estos dos elementos reside la particularidad de las actuales Constituciones del Estado burgués de Derecho. Esta duplicidad fija su estructura total y lleva a una duplicación correspondiente de conceptos centrales, como el concepto de ley (SCHMITT, 1982, p. 62).

Outro conceito chave para melhor compreensão do pensamento político deste autor é o de poder constituinte, diretamente relacionado ao de Constituição positiva. Schmitt assim apresenta-o:

Poder constituyente es la voluntad política cuya fuerza o autoridad es capaz de adoptar la concreta decisión de conjunto sobre modo y forma de la propia existencia política, determinando así la existencia de la unidad política como un todo. De las decisiones de esta voluntad se deriva la validez de toda ulterior regulación legal constitucional. 
Análise da Constituição do Estado Novo brasileiro a partir da ideia de constitucionalismo antiliberal...

Las decisiones como mías, son cualitativamente distintas de las normaciones legalconstitucionales establecidas sobre su base. [...] El poder constituyente es voluntad política: Ser político concreto. (SCHMITT, 1982, p. 93-94)

Dessa forma, para Schmitt, o poder constituinte é unitário e indivisível, englobando, fundamentando e conferindo legitimidade a todos os outros poderes que lhe são derivados (legislativo, executivo e judiciário), eis que este representa a vontade que concretiza a unidade política de um povo (SCHMITT, 1982, p. 95).

Partindo desse pressuposto de ausência de vínculo do poder constituinte a qualquer regulamento prévio, sendo este a representação da vontade política de um povo específico em um local e tempo específico, é evidente que o titular de tal poder pode variar, a depender da organização dessa sociedade e qual Constituição efetivamente a representa, podendo haver monarquias, democracias, aristocracias ou mesmo oligarquias com fundamento Constitucional (SCHMITT, 1982, p. 99).

Sendo o foco do autor a democracia ocidental de sua época, em sua análise o titular do poder constituinte é o povo, que delibera e toma decisões acerca de questões fundamentais como a forma política do Estado e sua organização. Entretanto, não sendo povo um conceito sólido, para evitar que sua vontade seja mal interpretada por aqueles que detém o poder burocrático, a forma correta de manifestação de sua vontade se dá mediante a aclamação da multidão reunida.

Se pode concluir que a vontade democrática do povo deve ser imediata, inexistindo representação. É anterior e superior a qualquer tipo de procedimento de legislação constitucional antecedendo qualquer deliberação realizada por representantes. Em síntese, a Constituição, encarada como decisão política, encontra seu fundamento na vontade política que a criou. Dessa forma, uma Constituição só seria reconhecida como legítima quando é reconhecida a autoridade do Poder Constituinte que manifestou a decisão fundamental. Esta decisão deve se apoiar em unidade política que já existe (SCHMITT, 1982, p. 104).

Cumpre também expor quais as premissas do Estado moderno que Schmitt leva em consideração em sua análise. Conforme exposto em ponto anterior, a moderna Constituição do Estado burguês de Direito é uma Constituição liberal, pois dá grande ênfase à liberdade individual, estabelecendo direitos fundamentais e garantias institucionais de proteção das liberdades do indivíduo contra atuação arbitrária do Estado (SCHMITT, 1982, p. 138).

Dessa forma, o conceito burguês de Estado de Direito teria as seguintes características: organização através da separação dos poderes, limitação quanto à liberdade individual prevista em lei (legalidade), competências rigorosamente circunscritas (Constituição como norma fundamental desse sistema organizacional) e possibilidade de controle judicial da administração pública (SCHMITT, 1982, p. 141-142).

Schmitt divide o conceito de lei em dois tipos: lei formal e lei material. Sob o aspecto formal, a lei é o produto da deliberação e decisão dos órgãos legislativos competentes, dentro de um processo pré-definido. Schmitt, contudo, distingue o conceito formal de um conceito político 
Análise da Constituição do Estado Novo brasileiro a partir da ideia de constitucionalismo antiliberal...

de lei - o político do jurídico, afirmando que na Constituição estes coexistem (SCHMITT, 1982, p. 153).

Este conceito político é derivado da forma de existência política do Estado e da formação concreta da organização dominante. Sob a ótica política, a lei é vontade e um ato de soberania, oriunda de um mandato concreto, que varia a depender da forma de organização social. Dessa forma, pode-se entender que, em uma democracia, lei é a vontade do povo. A partir desta ideia, Schmitt tece críticas ao Estado de Direito que, segundo o autor, constantemente vincula soberania à lei, enquanto em verdade esta existe concretamente e estabelece limites à liberdade e à propriedade (SCHMITT, 1982, p. 156).

Compreendida a lei sob a ótica do Estado burguês de Direito, ressalta-se que Schmitt relaciona-a com o conceito de igualdade. Para o autor, a igualdade perante a lei liberal é imanente ao conceito de lei próprio do Estado burguês de direito e sua compreensão está intimamente relacionada com a proibição de legislação em caráter geral (SCHMITT, 1982, p. 161-162).

Para Schmitt (1982, p. 224), essa igualdade burguesa não seria a real igualdade democrática, que é um conceito político autêntico e que, com base em seu conceito de político previamente exposto, deve sempre relacionar-se com uma possibilidade de diferenciação. Desta forma, a democracia real não pode basear-se em um conceito de igualdade geral entre todos os homens (indistinção), mas de um conceito interno de uma comunidade, havendo um sentimento de pertença de um povo (por razões como raça, fé, destino comum, mitos compartilhados e tradição). Portanto, dentro de um Estado democrático são iguais todos os súditos/cidadãos. Resume o jurista, acerca da verdadeira igualdade democrática:

La igualdad democrática es, pues, una igualdad sustancial. Todos los ciudadanos pueden ser tratados como iguales, tener igualdad ante el sufragio, etc., porque participan de esa sustancia. La sustancia de la igualdad puede ser diferente en las distintas Democracias y en las distintas épocas (SCHMITT, 1982, p. 225).

Esta é, portanto, a ideia de democracia substancial de Schmitt, baseada em um princípio de identidade de um povo que a concretiza através da Constituição (unidade política). O povo é o portador do Poder Constituinte e a organização do Estado, a divisão dos poderes e o exercício de atividades estatais é exercida por este método democrático, que conta com a mais ampla participação possível dos cidadãos (SCHMITT, 1982, p. 221).

Partindo deste ponto de vista, após a descrição dos conceitos fundamentais do Estado Democrático-Liberal, Carl Schmitt tece diversas críticas a esses conceitos baseados na ideia de pluralismo, eis que estes acabariam por possibilitar que forças políticas vivessem em eterno embate, firmando coalizões e pactos ambivalentes e oportunistas, não somente rompendo com a unidade política do povo, como rompendo com a representatividade entre o povo e o Estado (FERREIRA, 2010, p. 15-16).

La mayor oscuridad surge de que el concepto de Democracia, como tantos otros conceptos políticos, se ha convertido en un concepto ideal muy general, cuya pluralidad 
Análise da Constituição do Estado Novo brasileiro a partir da ideia de constitucionalismo antiliberal...

de sentidos abre plaza a otros diversos ideales y, por último, a todo lo que es ideal, bello y simpático. La Democracia se ha ligado e identificado con liberalismo, socialismo, justicia, humanidad, paz y reconciliación de los pueblos (SCHMITT, 1982, p. 223).

O Estado seria colocado no mesmo plano que as demais instituições, e o Parlamento, ao invés de um corpo representativo, se tornaria em uma espécie de balcão de interesses, sendo a política nacional decidida "nas antecâmaras" por forças políticas diversas e com interesses próprios (FERREIRA, 2010, p. 14).

Assim, esses interesses poderiam desfigurar uma ordem Constitucional aparentemente válida, ao destruir a unidade política que pressupõe a decisão fundamental manifestada na Carta Constitucional e atender aos interesses de grupos específicos em detrimento da decisão política do povo.

Encerra-se a abordagem da obra "Teoria Constitucional" de Carl Schmitt, de grande importância eis que desenvolve os principais temas a serem discutidos na prática, no Brasil, como Constituição, lei, igualdade e Democracia sob a ótica crítica e antiliberal do jurista alemão.

A seguir, passaremos a analisar os principais escritos de Francisco Campos, ao longo da trajetória de sua carreira, buscando verificar de que maneira as ideias desse autor convergem com os conceitos utilizados por Carl Schmitt, observando sua atuação como agente político e defensor do Estado Novo.

\section{O CONSTITUCIONALISMO ANTILIBERAL E SUA INFLUÊNCIA NO BRASIL DA ERA VARGAS: FRANCISCO CAMPOS E O ESTADO NOVO CONSTITUCIONAL}

Nesse tópico, abordar-se-á uma possível confluência das ideias de Carl Schmitt no direito constitucional brasileiro, notadamente através da figura do eminente jurista mineiro Francisco Campos, durante o período histórico conhecido como "Estado Novo" ou Terceira República Brasileira, regime político brasileiro instaurado pelo presidente Getúlio Vargas em 10 de novembro de 1937, vigorando até 31 de janeiro de 1946.

É importante esclarecer que o objetivo do presente trabalho não é analisar os motivos e objetivos ideológicos pessoais de Campos ao erigir as bases do governo excepcional instaurado, mas sim as influências pontuais do pensamento de Carl Schmitt na elaboração da do corpo jurídico do governo, levando em consideração a época e a movimentação política que ocorria no mundo às vésperas da $2^{\mathrm{a}}$ Guerra Mundial.

Em 1937, Getúlio Vargas (que havia chegado ao poder após a revolução de 1930), apoiado pelas forças armadas, fechou o Congresso, passando a governar através de decretos- leis. Vargas justificou tal atitude na necessidade de tomar medidas radicais destinadas a pôr fim à situação de conturbação da paz e política social, por fatores de desordem e desintegradores (BUENO, 2016, p. 85-86).

O principal documento jurídico que deu substância e base ao modelo de governo instaurado foi a Constituição de 10 de novembro de 1937, redigida por Francisco Campos que, naquele momento, ocupava o cargo de Ministro da Justiça. 
Análise da Constituição do Estado Novo brasileiro a partir da ideia de constitucionalismo antiliberal...

Em texto de 1914, intitulado "Democracia e Unidade Nacional", Campos denuncia suposto contraste entre a democracia e o princípio da unidade nacional, afirmando haver uma tensão entre esses dois conceitos antagônicos que orientam a organização social. Desta forma, as ideias separatistas e regionalistas da democracia, deveriam ser contrapostas pela ideia de centralização da autoridade, eis que esta seria a única maneira de expressar um princípio democrático sem colocar em risco a harmonia nacional (SANTOS, 2007, p. 287).

A diferenciação da autoridade e a multiplicação dos órgãos da soberania nacional são alvos da crítica de Campos, ao analisar a experiência histórica brasileira da passagem do Império à República, havendo o enfraquecimento da unidade nacional (SANTOS, 2007, p. 288).

Nesse sentido, Campos despreza a instabilidade dos conflitos e mudanças revolucionárias de governo, comuns às novas repúblicas das Américas, podendo ser identificado um traço de conservadorismo e tradicionalismo em seu pensamento inicial (BUENO, 2016, p. 84).

Todavia, Santos (2007, p. 296) aponta-o como um autor original de uma proposta Constitucional que tem preocupação com a condução das massas e a legitimação da autoridade do Estado, em um modelo cesarista e plebiscitário cuja classificação como autoritário seria insuficiente e problemática.

Em seu livro “O Estado Nacional: Sua Estructura e seu Conteúdo Ideológico” (1940), Campos desenvolve os argumentos jurídicos que fundamentam as disposições da Constituição de 1937, através da reunião de diversas entrevistas, conferências, discursos de Francisco Campos, sobre o período do Estado Novo, onde ocorre a defesa do Ministro ao governo de Getúlio Vargas. É nesta obra que resta clara a visão antiliberal que Campos tem do Estado e que pode ser diretamente relacionada à visão Constitucional de Schmitt.

A premissa básica seria o suposto anacronismo das instituições da democracia liberal diante das necessidades e vontades de uma sociedade de massas. A ideia do Estado Novo e o principal problema a ser enfrentado seria a organização do Brasil para um novo tempo, com a busca dos alicerces filosóficos do Estado. Campos defendia a necessidade deste novo tempo ser tutelado pela tradição, ante a incapacidade das lideranças políticas em lidar com as céleres mudanças que a democracia trazia, implicando na impossibilidade de se identificar normas de ação e de organização adequadas (SANTOS, 2007, p. 296-297).

Campos compreendia a política da atualidade em que vivia como uma época de transição para uma sociedade de massas, movida pela irracionalidade, pelos mitos, em que se buscava a figura de um césar. Portanto, essa realidade de uma sociedade de massas, não seria compatível com um sistema parlamentar representativo tradicional do Estado Liberal Burguês e sua afetação racional e no alongado debate de ideias e posições políticas e morais distintas.

Para Schmitt, a democracia indireta transforma-se, neste contexto, em algo indistinto do sistema parlamentar. $\mathrm{O}$ apelo à razão como centro decisório significa, da mesma forma, a submissão a uma lógica que violenta a individualidade concreta. A razão submete-se à unidade e à centralização política e religiosa da vida, articulada pela Ilustração e pela racionalidade da democracia moderna. Schmitt já indica qual é o sentido dessa crítica. Primeiramente, uma crítica ao racionalismo absoluto e ao seu 
Análise da Constituição do Estado Novo brasileiro a partir da ideia de constitucionalismo antiliberal...

desdobramento em ditadura da razão. Em segundo lugar, um estudo do mito como fundamento para uma doutrina da decisão ativa direta contra o racionalismo relativo da discussão pública e do parlamentarismo (Schmitt, 1994a [1921]:13). Schmitt entende ser válida a possibilidade de identificar a vontade popular concreta através da manifestação simples e imediata da massa através da aclamação popular (Zuruf, acclamatio) ou por obra de um indivíduo que encarne esta vontade (Schmitt, 1996a [1926]:6-7; 35). O autor vincula-se, assim, ao cesarismo como forma política por excelência. Forma de Estado ditatorial centrada na figura mítica do Líder. Este último necessita se legitimar pela ação emocional (irracional) das massas e intenta resolver "por cima" as tensões sociais em movimento (SANTOS, 2007, p. 305).

Nesse ponto, Santos (2007, p. 301) identifica o objeto de crítica comum de Schmitt e Campos como o fundamento intelectual da decisão política, havendo um interesse em compreender (e não em mudar) a democracia das massas, sua estrutura, funcionamento e irracionalidade, bem como a forma ideal de conduzi-la, entendendo isso como uma necessidade dos novos tempos (de transição).

Tanto Schmitt como Campos, como dito anteriormente, tem visões críticas e uma percepção específica da modernidade política e do constitucionalismo liberal. Para Schmitt, houve um processo contínuo de despolitização e romantização dos conflitos, afastando-se da tradicional forma de ver o mundo das culturas tradicionais como na Idade Média (afastamento da visão metafísica, espiritual do mundo).

A classe responsável por esse afastamento seria a burguesia, que privilegiou um sistema social focado sempre no conflito, resultante da rápida mudança de suas convicções, argumentos e justificativas, o que evidentemente gera muitas alternâncias de poder e afastamento da vontade popular, prejudicando sua unidade política, eis que "as explicações sobre o mundo irão mudar de acordo com conceitos culturais centrais e, para cada época, prevalecerá um modo de entendimento centralizado pelo conceito preponderante" (SANTOS, 2007, p. 298-299).

Segundo Santos (2007, p. 298-299) Schmitt afirma que, enquanto os conceitos chaves da política foram mudando no decorrer dos séculos (desde o século XVI, início da derrocada do racionalismo metafísico da teologia cristã, até o século XX, com o conceito "espiritual" do progresso técnico), há um distanciamento cada vez maior da realidade política, pois "todos os problemas de natureza política, moral, religiosa, social e econômica são remetidos ao desenvolvimento técnico, que os engloba em sua 'realidade' e os resolve magicamente". Eis aí a despolitização e neutralização dos conflitos políticos que Schmitt diagnostica como a causa da falência das instituições liberais.

Em Campos, o entendimento não é diferente, atribuindo a falência do mundo político contemporâneo a uma perspectiva romântica e irracional do modelo liberal de Estado e controle político. Não há constituição de valores supremos ou espirituais na modernidade, sendo qualquer valor tratado como relativo, simbólico, não gozando de valor teórico, sendo puramente emocionais. Desta forma, inexistindo uma ordem ou hierarquia de valores e uma grande dificuldade em definir seus conteúdos de forma conceitual e coerente, não há referência espiritual e, portanto, política que fundamente as relações sociais na sociedade contemporânea (SANTOS, 2007, p. 298-299). 
Análise da Constituição do Estado Novo brasileiro a partir da ideia de constitucionalismo antiliberal...

As massas identificadas por Campos são mobilizadas através de mitos e, portanto, irracionalmente. Mesmo não havendo possibilidade de manifestação sobre a substância de questões políticas pelas massas, inexistindo uma opinião racional sobre qualquer assunto, a mesma é capaz de tomar partido, sendo esse processo de escolha é manifestamente irredutível e ininteligível, sendo muito difícil inferir qualquer nexo lógico (SANTOS, 2007, p. 306).

Diante dessa dificuldade em se compreender as escolhas políticas das massas, Campos, assim como Schmitt, procura integrá-las e vinculá-las como parte da escolha democrática do líder, mesmo que esse seja um ditador, no sentido de conferir ordem e hierarquia nas decisões políticas que vier a tomar em nome das massas. Destarte, em ambos os autores há uma tentativa de integração lógica entre ditadura e democracia e um afastamento da vinculação necessária entre liberalismo e democracia.

Conforme visto em tópico específico sobre a teoria constitucional de Schmitt, o mesmo não se preocupa com o funcionamento da ditadura ou suas consequências práticas, mas apenas se preocupa com uma legitimação jurídica da mesma. Havendo a suspensão do funcionamento normal de uma norma em procedimentos que garantam sua eficácia futura, a ditadura seria somente mais um meio jurídico, ou seja, deve ser prevista pelo direito para garantir a existência de outras normas e a própria existência do ordenamento jurídico. Em resumo, havendo necessidade política, finalidade de realização e previsão constitucional, há a legitimação necessária para a instalação de uma ditadura, sendo somente necessária a positivação dessa possibilidade (e não uma ruptura amparada por conceitos como direito natural ou justiça). "O conceito de ditadura schmittiano é constitucional, antiliberal e, portanto, previsto no ordenamento jurídico" (SANTOS, 2007, p. 310).

Para Santos (2007), diante desse quadro de ditadura legitimada pela possibilidade positivada constitucionalmente, tal como previsto na teoria de Schmitt, é necessário considerar a Constituição de 1937 um elemento central na interpretação das instituições jurídicas do Estado Novo.

[...] Esse papel pode ser visto seja no processo de endurecimento do regime, seja por orientar a produção do corpo legislativo necessário à institucionalização do processo de modernização. Esse argumento é cristalino no texto de Campos: a falência política do liberalismo e a necessidade do distanciamento da forma política democrática das instituições liberais se estabelecem no século XX. Isto acontece dada a multiplicação do irracionalismo produzida pelas conquistas da ciência e da técnica. Esta opera, segundo ele, uma ressacralização da política, e a sua inscrição definitiva em um tempo em que a irracionalidade é constitutiva da configuração do poder político. Não é por outro motivo que, na Constituição de 1937, o instituto do plebiscito é o instrumento central de legitimação democrática do regime (SANTOS, 2007, p. 310).

A análise do texto da justificativa da Constituição de 1937, redigida por Francisco Campos permite, de fato, a identificação de certas semelhanças com elementos da obra de Carl Schmitt.

O PRESIDENTE DA REPÚBLICA DOS ESTADOS UNIDOS DO BRASIL, ATENDENDO às legitimas aspirações do povo brasileiro à paz política e social, 
Análise da Constituição do Estado Novo brasileiro a partir da ideia de constitucionalismo antiliberal...

profundamente perturbada por conhecidos fatores de desordem, resultantes da crescente a gravação dos dissídios partidários, que, uma, notória propaganda demagógica procura desnaturar em luta de classes, e da extremação, de conflitos ideológicos, tendentes, pelo seu desenvolvimento natural, resolver-se em termos de violência, colocando a Nação sob a funesta iminência da guerra civil; ATENDENDO ao estado de apreensão criado no País pela infiltração comunista, que se torna dia a dia mais extensa e mais profunda, exigindo remédios, de caráter radical e permanente; ATENDENDO a que, sob as instituições anteriores, não dispunha, o Estado de meios normais de preservação e de defesa da paz, da segurança e do bem-estar do povo; Sem o apoio das forças armadas e cedendo às inspirações da opinião nacional, umas e outras justificadamente apreensivas diante dos perigos que ameaçam a nossa unidade e da rapidez com que se vem processando a decomposição das nossas instituições civis e políticas; Resolve assegurar à Nação a sua unidade, o respeito à sua honra e à sua independência, e ao povo brasileiro, sob um regime de paz política e social, as condições necessárias à sua segurança, ao seu bem-estar e à sua prosperidade, decretando a seguinte Constituição, que se cumprirá desde hoje em todo o País: [...].

É perceptível que o fundamento e justificativa para a ruptura constitucional e a utilização de termos como "situação de perturbação e desordem", "decomposição das instituições civis e políticas" e "guerra civil" são indicativas da influência do conceito do político e a distinção amigo-inimigo, dado que há a clara nomeação do inimigo público: a infiltração comunista. A obra "O Conceito do Político", de Carl Schmitt, pode ter inspirado a redação do referido texto constitucional (deixando-se claro que se trata de suposição do autor deste texto).

Veja-se que o Estado, na figura carismática do Presidente da República, ao verificar a iminência de uma suposta guerra civil, decide tomar medidas para proteger a ordem existente, através de "remédios radicais e permanentes". Bueno identifica essa aplicação direta da teoria de Schmitt, afirmando que Campos projetou na imagem de Vargas a figura do soberano irradiador da vontade política:

Embora sem referência expressa, Campos aplicou a teoria schmittiana ao identificar
o Estado Novo à figura de Vargas, radiante e transcendente figura, ao tempo em que
análoga ao Estado. Associando Vargas à virtude no Estado, o soberano é posicionado
como centro do universo espiritual, irradiador da vontade política, sendo o Estado
executor da realização dos seus intuitos, guiado por programas inspirados na pura
projeção da vontade soberana. Esta vontade suprema do soberano preenche de
sentido as ações do ente estatal, que empresta o seu poder concreto e toda força para
realizar o querer do soberano no mundo, à semelhança da Igreja com a divindade, e
daí a transferência da legitimidade política de sua base popular para esfera mítico-
transcendente, de uma concepção liberal do Estado de Direito em que as leis governam
os homens para o império do puro arbítrio sobre o direito (BUENO, 2016, p. 83).

Conforme exposto anteriormente, se não se pode compreender o fundamento das decisões das massas, se pode mobilizá-las através do mito político e forma eficaz de se realizar essa mobilização é através da figura carismática de um “César", ligado diretamente ao povo, sem intermediários. Campos compreende perfeitamente esse raciocínio de Schmitt e não lamenta tal realidade, apenas procura entendê-la, para adaptar o Estado brasileiro e garantir a continuidade de uma democracia real, concreta e unitária no país. A massa irracional concretiza e corporifica 
Análise da Constituição do Estado Novo brasileiro a partir da ideia de constitucionalismo antiliberal...

a força política, dando unidade ao país e força para o enfrentamento político. Essa é a visão de democracia substantiva aplicada por Campos no Brasil, ao garantir o substrato técnico formal do direito ao Estado Novo.

Ante o exposto acima, resta clara a conclusão de que o conceito de democracia que orienta a construção constitucional de ambos os autores (Schmitt e Campos) é a democracia substantiva ou substancial, em oposição ao conceito formal do liberalismo.

[...] No conceito de democracia substancial, já como ministro do Estado Novo, Campos usa a Verfassunglehre (1993 [1928]) de Schmitt como fonte, eventualmente citada em outros escritos. Em diálogo não assumido, ele demonstra compreender a distinção entre dois modelos constitucionais, entre duas estruturas institucionais que não se confundem: as democráticas substantivas (antiliberais) e as democráticas formais (liberais). Ele demarca o conceito de democracia substantiva que passa a informar a composição constitucional do Estado Novo (SANTOS, 2007, p. 311).

Roberto Bueno (2016, p. 87-93) explica que no Brasil utilizou-se argumentação similar à de Carl Schmitt - de que a ditadura não seria o oposto da democracia - para conferir ao Estado Novo de Getúlio Vargas o status de república democrática e representativa, que promovia o nacionalismo trabalhista e a democracia substancial. Para Schmitt, a identidade é o verdadeiro princípio democrático, eis que indica igualdade substancial entre governantes e governados. Quanto mais densa e absoluta for a homogeneidade do povo, mais forte e decidido será o governo. A identidade e a representação determinam a unidade política do povo e o tornam capaz de agir como unidade. A ditadura, para Schmitt, não é o oposto de democracia.

Nesse ponto, faz-se necessária a distinção conceitual do que seria a democracia substancial sob a ótica antiliberal de Campos (influenciado por Schmitt) em contrapartida ao conceito de democracia representativa do Estado Liberal, retomando conceitos expostos no tópico 2.2.

A democracia substancial, como estabelecida por Carl Schmitt em seu livro "Teoria da Constituição", é diretamente relacionada à ideia de comunidade específica, na qual há identidade e homogeneidade moral e política em um determinado espaço (físico) e tempo. Essa comunidade, ou povo, será capaz de manifestar sua vontade política de forma direta, sem a necessidade de intermediação de instituições representativas de sua vontade, se distanciando do conceito de racionalismo liberal das democracias modernas. Para o autor alemão, não haveria porquê basear a estrutura jurídica de uma nação fundamentando-se na ideia de universalidade e igualdade absoluta de direitos políticos, eis que a realidade impõe claras diferenças (naturais, individuais, desigualdades de fato além da própria diferença cultural e política entre os povos, que possuem identidades nacionais distintas).

Dessa forma, sua ideia de democracia é totalmente distante das democracias contemporâneas, formais e de representação indireta (usualmente tem como forma e instituição mais representativa o parlamento), obedecendo a um número de procedimentos e de instituições que intermedeiam a relação política entre o povo e o Estado, garantindo formalmente a liberdade de manifestação, a partidarização e a pluralidade ideológica político-partidária. 
Análise da Constituição do Estado Novo brasileiro a partir da ideia de constitucionalismo antiliberal...

A democracia substancial, por sua vez, representa a legitimação da mobilização social irracional destituída de controles formais, ou seja, é contrária a procedimentos que pretendam garantir racionalidade ao processo político (SANTOS, 2007, p. 311). Acerca do conceito de democracia para Carl Schmitt, em passagem de sua Teoria da Constituição:

[...] La igualdad democrática es, en esencia, homogeneidad, y, por cierto, homogeneidad del pueblo. [...] III. Definición de Democracia. Democracia (tanto en cuanto forma política como en cuanto forma del Gobierno o de la Legislación) es identidad de dominadores y dominados, de gobernantes y gobernados, de los que mandan y los que obedecen (SCHMITT, 1982, p. 230-231).

Com base nesse conceito, se pode perceber uma possível ligação com a defesa de Francisco Campos de que o Estado Novo seria democrático, sob o fundamento de que a vontade do povo brasileiro se identificava com a de seu então governante, Getúlio Vargas.

Segundo Bueno (2016, p. 87), a ideia de democracia em Campos era totalmente distinta da concepção liberal formalista, razão pela qual a classificação do Estado Novo como democrático seria possível. O novo conceito (substancial ou substantiva), influenciado por Schmitt, envolvia a ideia de aptidão para a dissolução e resolução de conflitos derivando tal legitimidade de uma ideia autoritária. Uma democracia de "viés autoritário" onde haveria uma conexão direta entre o povo (sociedade homogênea) e o seu líder. Veja-se:

O movimento de Campos desenhava uma concepção de sociedade unitária, compatível com a essência de Estado cuja via autoritária destituía a esfera privada de seu potencial contestatório. Para tanto, pressuposto era a força, livre de processos e instituições demoliberais limitadoras, insistentes em infrutíferos debates fechados em comissões cuja pauta era distanciada do interesse público, inversamente ao Estado corporativo positivado na Constituição Brasileira de 1937 (BUENO, 2016, p. 88).

É importante observar que essa defesa, mesmo amparada por uma forma jurídica e constitucional não se sustentou por muito tempo. Tal fato se deu em razão das cortes brasileiras serem eminentemente de formação liberal. Segundo Santos (2007, p. 313):

O Estado de Direito pressupõe divisão de poderes, representação parlamentar, sufrágio, garantias individuais, limitações constitucionais ao poder político, concentração da atividade legislativa no Poder Legislativo - e não no Poder Executivo - além de limitações formais e substanciais à decretação e permanência do estado de sítio, por exemplo. Nenhum desses institutos, no seu caráter estritamente liberal, pode ser encontrado na Constituição escrita por Campos.

Em termos jurídicos, a utilização da Constituição como instrumento de legitimação da ditadura significa o deslocamento da função legislativa para a burocracia do Poder Executivo, algo totalmente incompatível com o princípio liberal da divisão de poderes. Essa incompatibilidade resta clara quando a doutrina de Schmitt preconiza a atuação democrático-substancial do Estado burocrático-administrativo executor em detrimento da legalidade do Estado burguês. 
Análise da Constituição do Estado Novo brasileiro a partir da ideia de constitucionalismo antiliberal...

No caso brasileiro, Campos vai além e, ao justificar o modelo constitucional que deu forma ao Estado Novo, explicita os princípios da nova ordem política por ele confeccionada. O autor afirma que o ideal revolucionário só poderia se realizar pela alteração das instituições. Em crítica direta ao localismo oligárquico (na visão de Campos, a Constituição de 1934 significou uma restauração do poder dessas oligarquias da Velha República), passa a criticar o modelo partidário da república através da censura à existência de partidos, afirmando sua demagogia e demandando reforço à autoridade do Poder Executivo (SANTOS, 2007, p. 315).

Enquanto o Parlamento deveria cuidar politicamente dos fatos mais relevantes da vida nacional através da legislação, a administração pública, pelo seu poder regulamentar e na expedição de decretos-leis, organizaria, tecnicamente, os detalhes do cotidiano. O autor aproveita-se, desta forma, não só de uma estrutura teórica já utilizada por um conjunto de constituições européias da época, como a realizará na Constituição de 1937, compondo-a com instrumentos constitucionais delimitadores do modelo de Estado antiliberal (SANTOS, 2007, p. 315).

Segundo Bueno (2016, p. 90), Campos questionava a manutenção dos partidos políticos e colocava sua estrutura burocrática como empecilho para a resolução dos problemas sociais. Essa posição seria explicada pela suposta incapacidade dos partidos políticos para conduzir o debate político e a organização dos interesses públicos. Destarte, favoreceu um ideal político autoritário apostando em uma versão da democracia sem intermediários.

Bueno (2016, p. 93-97) chega a perceber traços weberianos no antiparlamentarismo característico de Schmitt e Campos, no sentido de que a burocracia técnica do Poder Executivo seria mais eficiente na tomada de decisões (havendo aí uma predominância da vontade sobre a deliberação), colocando-se as discussões parlamentares como fictícias, formalidades vazias, pois se limitavam a negociatas privadas momentâneas de indivíduos despreparados para lidar com a crescente complexidade da legislação. Diz Bueno:

\footnotetext{
A crítica campista-schmittiana sobre a democracia parlamentar ocorreu em cenário de difundida percepção pública de que a estrutura parlamentar era inepta, que as demandas de modernização deveriam ser mediadas e coordenadas por elite bem instruída e por organização burocrática eficiente, distanciada dos eternos diálogos parlamentares. Para Campos e a visão aristocrático-elitista conservadora apenas uma elite política seria capaz de conduzir a burocracia estatal de modesta vinculação weberiana, reconhecendo ser problema capital das democracias a constante eleição de indivíduos despreparados tecnicamente para o desempenho de relevantes funções de governo e legislação, incapacidade supostamente comum a diversos países (BUENO, 2016, p. 94).
}

É de bom alvitre ressaltar que Campos, assim como Schmitt, tende a distanciar-se do então vetor de legitimação imanente do Estado Liberal. Em que pese a justificação de poder ser imanente (não se justifica o voluntarismo do governo com base em uma superioridade ou descendência divina dos governantes), ela encontra guarida em categorias pré-modernas, eis que enxerga uma infalibilidade no Poder Executivo que poderia ser comparada a um modelo teológico. 
Análise da Constituição do Estado Novo brasileiro a partir da ideia de constitucionalismo antiliberal...

Se as cláusulas pétreas serão os pressupostos básicos de organização política e jurídica da vida social e o povo não poderia decidir o seu conteúdo (que seria decidido pelo Poder Executivo), bem como tal decisão também fosse afastada do Parlamento, é certo que incorrerá em um inevitável voluntarismo elitista, uma ditadura irracional da vontade, onde tanto Schmitt quanto Campos parecem enxergar a verdadeira democracia substancial (BUENO, 2016, p. 96-97).

Por fim, questão que merece destaque acerca da influência da teoria política de Schmitt na Construção do aparato legal do Estado Novo é a regulação da declaração de inconstitucionalidade de leis. Segundo Bueno, há um afastamento da prerrogativa do Poder Judiciário em declarar a inconstitucionalidade de leis:

\footnotetext{
Uma das vias institucionais para a eliminação das dissonâncias - confundidas com cru e radical antagonismo político - e consolidação do Estado forte se encontrava na opção campista pela teoria schmittiana da supremacia do político sobre o jurídico, algo que, no caso do controle de constitucionalidade, concentraria poderes no Poder Executivo, e não mais no Poder Judiciário (BUENO, 2016, p. 88).
}

A Constituição de 37 permite que o parlamento remova inconstitucionalidades através de nova votação de lei, em seu art. $174^{1}$. Contudo, para se utilizar dessa prerrogativa, seria necessário que o presidente tomasse a iniciativa e de que se tratasse de caso de interesse nacional, exigindo-se a votação por dois terços nas duas Câmaras. Ademais, caso houvesse discordância entre o Poder Executivo e o Legislativo, o projeto seria submetido a plebiscito nacional para avaliação de sua constitucionalidade.

Ademais, afora os poderes largamente majoritários do Poder Executivo em face do Poder legislativo na definição e aprovação de leis, ainda destaca-se o total desprestígio do Poder Judiciário, restando evidente que Campos não vê como essencial que este detenha a prerrogativa de declaração de inconstitucionalidades de leis ou de recusar a sua execução, tal como evidenciado na impossibilidade de discussão de questões exclusivamente políticas ou exigência de maioria absoluta de votos da totalidade da composição do tribunal para a declaração de inconstitucionalidade de lei ou mesmo de decretos do Presidente da República².

1 Art. 174 - A Constituição pode ser emendada, modificada ou reformada por iniciativa do Presidente da República ou da Câmara dos Deputados.

$[\ldots]$

$\S 3^{\circ}$ - O projeto de emenda, modificação ou reforma da Constituição, quando de iniciativa da Câmara dos Deputados, uma vez aprovado mediante o voto da maioria dos membros de uma e outra Câmara, será enviado ao Presidente da República. Este, dentro do prazo de trinta dias, poderá devolver à Câmara dos Deputados o projeto, pedindo que o mesmo seja submetido a nova tramitação por ambas as Câmaras. A nova tramitação só poderá efetuarse no curso da Legislatura seguinte, salvo quanto ao projeto elaborado na primeira Legislatura, o qual tramitará durante esta e prevalecerá se obtiver o voto de dois terços dos membros de uma e outra Câmara.

$\S 4^{\circ}$ - No caso de ser rejeitado o projeto de iniciativa do Presidente da República, ou no caso em que o Parlamento aprove definitivamente, apesar da oposição daquele, o projeto de iniciativa da Câmara dos Deputados, o Presidente da República poderá, dentro de trinta dias, resolver que o projeto seja submetido ao plebiscito nacional. O plebiscito realizar-se-á noventa dias depois de publicada a resolução presidencial. O projeto se transformará em lei constitucional se lhe for favorável o plebiscito.

2 Art. 94 - É vedado ao Poder Judiciário conhecer de questões exclusivamente políticas.

Art. 96 - Só por maioria absoluta de votos da totalidade dos seus Juízes poderão os Tribunais declarar a inconstitucionalidade de lei ou de ato do Presidente da República. 
Análise da Constituição do Estado Novo brasileiro a partir da ideia de constitucionalismo antiliberal...

Estes são os principais aspectos da obra de Francisco Campos, que reputa-se como de interesse para o estudo da recepção das ideias de Carl Schmitt em sua obra. Encontra-se, portanto, em textos da Constituição de 1937, bem como em textos esparsos citados em outras obras de autores que estudaram os pareceres e obras de Campos, uma forte defesa do governo constitucional antiliberal do Estado Novo com argumentos semelhantes àqueles utilizados por Carl Schmitt, tais como democracia substantiva, sociedade de massas irracional, a figura mítica do governante, o alargamento dos poderes da burocracia Executiva, a positivação constitucional de uma ditadura concreta, unidade política nacional, homogeneidade do povo, ligação direta entre governantes e governados o desprezo ao formalismo e racionalismo do liberalismo político característico do Estado moderno burguês.

\section{CONSIDERAÇÕES FINAIS}

Conforme exposto, no presente artigo buscou-se compreender as semelhanças entre as ideias de Carl Schmitt e o direito constitucional brasileiro, no período compreendido entre 1930 a 1945. A hipótese central é a de que as ideias de Schmitt convergem com os pensamentos políticos de Francisco Campos em sua defesa do governo antiliberal do Estado Novo.

Dedicou-se o primeiro capítulo à exposição das principais ideias de Carl Schmitt que poderiam ter sido recepcionadas no direito constitucional brasileiro, por meio das obras "O Conceito do Político" e "Teoria da Constituição", onde são trazidos os conceitos de Estado e do político, com suas categorias de amigo e inimigo e sua Teoria Constitucional, com os conceitos de Constituição, poder constituinte, bem como dos elementos característicos do Estado burguês de Direito.

No segundo capítulo, foi analisada a obra de Francisco Campos, buscando semelhanças conceituais com o pensamento político e jurídico de Schmitt. Campos não foi tomado como um simples intelectual autoritário defensor das ideias de Carl Schmitt, eis que se adotou a concepção de Rogério Dultra dos Santos de que se tratava de pensador adaptável e realmente preocupado com a legitimação positiva do regime, considerando-o democrático.

Em análise do texto da Constituição outorgada de 1937, foram encontrados alguns elementos da obra de Carl Schmitt, como, por exemplo, na justificativa, onde afirma-se que o país estava sob iminência de guerra civil, estando a paz e a ordem perturbadas, com a clara identificação de um inimigo público (os comunistas), havendo influência da obra "O Conceito do Político".

Ademais, foi identificada a previsão do uso de plebiscito popular, no art. 187. Conforme exposto, esse era um dos procedimentos que Carl Schmitt entendia como democráticos de implantação de texto constitucional.

Na obra "O Estado Nacional”, Francisco Campos fez a defesa do regime autoritário do Estado Novo. Há diversas semelhanças entre essa obra de Francisco Campos e as ideias de 
Análise da Constituição do Estado Novo brasileiro a partir da ideia de constitucionalismo antiliberal...

Carl Schmitt no que concerne ao conceito de democracia como identidade entre governantes e governados, não sendo uma ditadura a antítese necessária da democracia. Assim, percebe-se uma possível ligação com a defesa de Francisco Campos de que o Estado Nacional seria democrático, sob o fundamento de que a vontade do povo brasileiro se identificava com a de seu governante Getúlio Vargas.

Visando ao controle da sociedade de massas, o Estado estruturado por Campos, autor exclusivo da Constituição de 1937, funciona através de uma burocracia estatal que é focada no agigantamento do Poder Executivo, cuja sustentação depende do mito do César. As transformações políticas e os problemas enfrentados pelo liberalismo político na Europa do início do Século XX influenciam o pensamento de Campos, que procura uma técnica jurídica capaz de dominar as massas pela via irracional do mito, em um modelo de Estado não simplesmente autoritário, mas antiliberal e plebiscitário.

A justificação jurídico-constitucional do Estado Novo se deu através de transferência do Poder Legislativo para o Executivo, dando protagonismo constitucional a instrumentos de manutenção do poder político, como o estado de emergência, bem como a de aproximação direta entre governante e as massas, como o plebiscito popular. Estas novas abordagens constitucionais aproximaram o Brasil de um antiliberalismo cujas características eram compartilhadas por várias constituições do Ocidente.

Por fim, é através da teoria constitucional de Campos que se percebe sua grande influência e importância na história do Direito no Brasil. A relação de emergência que o mesmo constrói na política brasileira, através da crítica que seu constitucionalismo antiliberal dirige ao liberalismo é decisiva para a consolidação de um entendimento que muitos atores políticos (conservadores e socialistas) até hoje tem em mente quando discutem a eficácia da democracia: a ideia de que o parlamento não acompanha a dinâmica dos fatos e não representa a verdadeira vontade do povo.

No entanto, enquanto a maioria das ideias liberais procuram adequar a atuação do parlamento e aproximar a representação político-partidária ao máximo de uma maior participação popular, a solução proposta por Campos era mais apressada e direta: as instituições públicas deveriam se ajustar às exigências dos fatos e conflitos sociais no tempo pela exceção. Isso traria legitimidade a qualquer governo central, eis que a emergência dos fatos o justificaria. O problema que Campos não respondeu e até hoje persiste é: por quanto tempo esse arranjo provisório rápido, flexível e adaptado à rapidez dos tempos modernos se sustentaria, sem a completa extinção de direitos e liberdades dos indivíduos?

Esse trabalho não teve a pretensão de julgar as razões políticas de Campos, mas compreender seu pensamento e influências, com o fito de observar melhor a evolução do direito constitucional no Brasil e o que ainda pode ser pensado para o futuro, fora da perspectiva de um Estado Liberal. A busca da compreensão do fenômeno da recepção das ideias de Carl Schmitt no direito constitucional brasileiro é uma das claves para uma confirmação da validade dessa empreitada. 


\section{REFERÊNCIAS BIBLIOGRÁFICAS}

BRASIL. Constituição (1937). Constituição dos Estados Unidos do Brasil, de 10 de novembro de 1937. Rio de Janeiro, [1937]. Disponível em: http://www.planalto.gov.br/ ccivil_03/Constituicao/Constituicao37.htm. Acesso em: 20 ago. 2020.

BUENO, Roberto. Francisco Campos e o autoritarismo brasileiro: um diálogo oculto com Carl Schmitt. Res Publica. Revista de Historia de las Ideas Políticas, v. 19, n. 1, p. 77-98, 2016.

FERREIRA, Bernardo. Crise da ordem liberal e pensamento constitucional em Carl Schmitt. In: CONGRESO LATINOAMERICANO DE CIENCIA POLÍTICA, 5, 2010, Buenos Aires. [Anais]. Buenos Aires: Alacip, 2010. p. 1-10.

SANTOS, Rogerio Dultra dos. Francisco Campos e os fundamentos do constitucionalismo antiliberal no Brasil. Dados, v. 50, n. 2, p. 281-323, 2007.

SCHMITT, Carl. O conceito do político. Teoria do Partisan. Belo Horizonte: Del Rey, 2008. . Teoría de la Constitución. Madrid: Alianza, 1982. 